DOI: $10.31393 /$ reports-vnmedical-2020-24(3)-26

UDC: $616-022.6-053: 616.155 .2 / .294$

\title{
FEATURES OF PATHOGENETIC MECHANISMS OF THE INTERACTION OF VIRUSES AND PLATELETS IN PATIENTS WITH IMMUNE THROMBOCYTOPENIA (REVIEW OF LITERATURE)
}

\author{
Dudnyk V. M., Furman V. H., Izuymets O. I., Fedchishen A. P., Sinchyck N. I., Kutsak O. V.
}

National Pirogov Memorial Medical University, Vinnytsya (Pyrogov street 56, Vinnytsya, Ukraine, 21018)

Responsible for correspondence: e-mail: Furmanv62@gmail.com

Received: July 17, 2020; Accepted: August 28, 2020

Annotation. One of the urgent interdisciplinar problems of modern medicine is to study the mechanisms of development of virusinduced thrombocytopenia in patients. The aim is to sum up current knowledge of viruses and platelets interaction, how viruses affect platelet and modulate adaptive immune response. A systematic review of the articles in the Pub Med database was conducted between 2007 and 2020, using search terms: platelets, thrombocytopenia, viral infection. Current data on the study of the mechanisms of platelet interaction with different types of viruses in immune thrombocytopenia in children were analyzed. We studied activation of platelets by a viral infection and how the immune response works. We know that the immune response is a cyclic multistage process involving T-lymphocytes, B-lymphocytes, macrophages, cytokines, Nk-cells. Antiplatelet antibodies are increase platelet clearance from the blood. The combination of antibodies with platelets leads to phagocytosis. In patients with immune thrombocytopenia IgG antibodies are produced against GP/II b/III or GP/I b/IX glycoproteins located on the platelet surface. In this situation it is possible to produce antibodies of other subclasses of $\mathrm{g} \mathrm{G}$, also a complement of fixing $\mathrm{lg} \mathrm{G}$, rarelylg A to other glycoprotein, or to other complexes Ib IX, la/lla. Since megakaryocytes express glycoprotein IIb/llla, lo as well as other platelet antigens, they become a target for autoantibodies. Viruses can interact directly with platelets and megakaryocytes. In addition, platelets can be activated by viral antigenantibody complexes and B- lymphocytes can produce antiplatelet antibodies. All of these processes are activate platelets and lead to increased consumption and remove of platelets, this causes hemorrhagic manifestation in patients.

Keywords: platelets, thrombocytopenia, virus infection, patients.

\section{Introduction}

Thrombocytopenia accompanies the course of many diseases that differ in pathogenesis and clinical features. Establishing causal factor is important, as it determines the treatment tactics and the possibility of early prevention of its irreversible consequences [2]. According to an expert group of the American Society of Hematologists (2008), in $95 \%$ of cases, thrombocytopenia has no direct explanation or connection with any causes or conditions that can cause them. In such cases, immune thrombocytopenic purpura (ITP) is diagnosed. The acute form of ITP is more common in children and ends in complete recovery in $75 \%$ of cases. Among adults, the chronic form of ITP is more common. Unfortunately, statistics show that $5 \%$ of adults who develop ITP die from hemorrhage, mainly in the brain. Due to the fact that there are currently no specific criteria for the diagnosis of ITP, the basis for the diagnosis is the exclusion of any cause of secondary thrombocytopenia [1, 2, 17].

It is known, that the incidence of thrombocytopenic purpura (TP) in the world is $1.6-3.9$ cases per 100 thousand populations per year, the prevalence ranges from 4.5 to 20 cases per 100 thousand populations. Thrombocytopenia has no geographical features. Men get sick 5-6 times less often than women. TP is more common in people aged 20 to 40 years $-54 \%$ of patients, from 40 to 60 years - $30 \%$ and very rarely younger than 20 and older than 70 years $(5 \%$ and $11 \%$, respectively) [18]

The structure of triggers of TP: infectious processes (often viral) - 59\%, pregnancy - 19\%, stress - 15\%, surgical manipulations - in $4 \%$, exercise - in $2 \%$, vaccines - in $1 \%$ of patients [13]. The largest proportion in this group are immune thrombocytopenias. Thrombocytopenia in infection occurs by direct suppression of bone marrow function or increased peripheral platelet intake. Approximately $30 \%$ of patients with sepsis have thrombocytopenia due to inhibition of megakaryocyte growth in infections caused by gram-positive and gramnegative bacteria or fungi $[5,19]$.

TP is often found in the presence of hepatitis B and C viruses, chickenpox, rubella, mumps, Epstein-Barr virus, HIV, cytomegalovirus, parvovirus B19 [20].

The mechanism of development of TP of immune character includes emergence of antibodies of different direction - autoantibodies to megakaryocytes and thrombocytes; autoantibodies to platelets; antibodies against auto- or xenoantigens that are adsorbed on the surface of platelets; antibodies against immune complexes that bind to platelets.

Autoimmunisation against platelets can occur due to a number of reasons: infection (viral, rarely bacterial), preventive immunization, hypothermia, mental and physical trauma, medication, allergic and shock conditions.

Viruses play a special role in the occurrence of the autoimmune process. It is known that viruses can infect bone marrow cells directly, destroying them. Viruses can 
cause the induction of an autoimmune response due to: the production of antiidiotypic antibodies to antiviral antibodies; enhancing the expression of MCH-HLA class I and II molecules, which are very similar to certain areas of viral genomes; molecular mimicry between viruses and platelets; violation of the host's immune response; changes in endogenous antigens.

In recent years, there has been growing evidence that platelets can modulate the innate and adaptive immune response. In addition, platelets can be activated by viral antigen-antibody complexes, and in response to some viruses, B-lymphocytes can generate antiplatelet antibodies. All these processes that promote platelet activation lead to increased consumption and removal of platelets.

The aim the analyses the professional literature on the generalization of current knowledge about the interaction of platelets with different types of viruses, the viral effect on platelet activation and platelet-mediated modulation of adaptive immune responses.

\section{Materials and methods}

A systematic review of the articles in the Pub Med database was conducted between 2007 and 2020, using the search terms: platelets, thrombocytopenia, and viral infection.

\section{Results. Discussion}

Thrombocytopenia is common after viral infections, and viruses use different strategies to reduce circulating platelet counts. Virus-mediated thrombocytopenia is often multifactorial and has its own mechanisms of occurrence $[5,8]$.

The immune response underlying the development of thrombocytopenia is a cyclic multistage process involving T-lymphocytes, B-lymphocytes, macrophages, cytokines, NK cells. Antiplatelet antibodies accelerate the clearance of platelets from the circulation. Binding of antibodies to platelets results in Fcy receptor-mediated platelet breakdown by phagocytes. Patients with idiopathic thrombocytopenic purpura produce mainly Ig G autoantibodies against glycoproteins GP/II b/III a or GP/l b/ IX platelet surface. In this situation, it is possible to produce antibodies of other subclasses Ig G, complement fixing Ig $M$, and less often, $\lg A$ to other glycoproteins, or to their complexes, such as Ib IX, la/lla. Because megakaryocytes express glycoprotein Ilb/IIla, Ib, and other platelet antigens, they also become a target for autoantibodies [2].

Today, modern methods for detecting antiplatelet antibodies are: thromboagglutination, complement binding reaction, direct and indirect antiglobulin consumption tests, platelet immunofluorescence test (PFIT), enzyme immunosorbent enzyme (ELISA), antimotrobial antimotarization method. Two different methods are usually used to detect antibodies to platelets. The most accessible and informative are PFIT in combination with ELISA [1].
It has been shown that reducing the number of platelets to $85 \%$ of all circulating in the blood is sufficient to maintain vascular integrity [11]. In a lymphocytic choriomeningitis virus model, mice with severe thrombocytopenia were shown to develop only local hemorrhage at the site of inflammation, and that bleeding dependent on lymphocytic choriomeningitis virus was the result of platelet / IF dysfunction caused by IF. Mice lacking the functional IFNa/ $\beta$ receptor have less pronounced anemia and hemorrhage due to the restored ability of platelet aggregation during infection with this virus [10]. This indicates that platelet dysfunction has more stunning consequences than thrombocytopenia in these pathologies.

Note that many hemorrhagic fever viruses inhibit platelet function. Juninin virus, the causative agent of Argentine hemorrhagic fever, induces a decrease in the signaling dependence of IFNa/ $\beta$ in the production and function of platelets. Ebola virus also induces an increase in IFNa, which correlates with increased mortality. The Ebola virus additionally induces the expression of TF associated with Ebola hemorrhagic fever. Gantavirus and lasavirus also cancel the platelet response due to plasma-mediated inhibition of platelets and / or their direct interaction [8].

The disintegration of the pathological complex of hypertension occurs by its destruction in the spleen and by cytostatic and complement-dependent lysis. T-lymphocytes play a significant role in the formation of the immune response in thrombocytopenia. There is an increase in the ratio of subpopulations Th1/Th4 (CD4 + helpers), Ts1/Ts2 (cytotoxic CD8 + cells), decreases the number of regulatory CD4 +, CD25 + T lymphocytes) [2].

Although thrombocytopenia is common in patients with Dengue virus, bleeding is rare. However, if bleeding occurs, they are associated with a high risk of mortality. Note that in those infected with the Dengue virus, the platelet count does not predict the risk of bleeding. However, systemic platelet activation may contribute to the procoagulant status in these patients, who often develop DIC syndrome [12]. Influenza H1N1 infection enhances the activation of circulating platelets and leads to increased thrombosis events [10]

Platelet dysfunction increases the risk of hemorrhage and, consequently, mortality. Animal experiments have shown that pharmacological inhibition of either platelets or the coagulation cascade increases the mortality of H1N1infected mice [7]. Aspirin treatment, which inhibits platelet activation through cyclooxygenase inhibition and subsequent TxA2 production, hypothesized that aspirin reduced the incidence and severity of the influenza pandemic in the 1910s.

The heteroimmune nature of thrombocytopenia is observed in newborns. Antibodies are produced against an antigen located on the surface of platelets [6].

Hemorrhagic syndrome caused by thrombocytopenia is observed in $25 \%$ of all newborns. Infectious and inflammatory diseases $(64.8 \%)$ are the most common 
cause of neonatal thrombocytopenia. Intrauterine, especially viral infections in $7.0 \%$ of newborns cause hemorrhagic syndrome. Immune thrombocytopenia in neonates with intrauterine infection occurs due to insufficient production of platelets by the bone marrow. It is proved that at the same time the lacing of platelets from the megakaryocyte sprout by pathogen toxins, the phenomenon of hypersplenism, DIC syndrome is inhibited. Manifestations of hemorrhagic syndrome caused by thrombocytopenia in newborns with intrauterine infection depend on the type of pathogen and the gestational age at which the infectious agent affected the fetus $[1,6]$. Detection of diagnostically significant increase in antibody titer to any pathogen Barr, rubella virus, herpes simplex, etc.) confirms the secondary nature of thrombocytopenia (heteroimmune forms of the disease) [3,6].

Viruses can regulate the process of platelet formation. Viruses affect the cytokine profile of the host, which in turn leads to changes in the production of thrombopoietin (TP) in the liver in Simian immunodeficiency virus (SIV), human herpes virus 6 , which can interfere with the proliferation of megakaryocytes, human herpes virus 7 , which can disrupt the differential megakaryocytes [8, 9].

Hepatitis $\mathrm{C}$ virus (HCV) disrupts the production of TP by destroying liver tissue, resulting in reduced TP synthesis, which leads to delayed synthesis of megakaryocytes and platelets. Infection of bone marrow stromal cells and hematopoietic stem cells changes the production of cytokines and reduces the number of progenitor cells, thereby disrupting hematopoiesis. Virus-infected megakaryocytes have been shown to express less surface c-Mpl, which is a receptor for TP [8].

Studies show that seropositivity to CMV or HCV is an independent marker of cardiovascular risk. CMV and HCV are additionally associated with increased graft rejection, restenosis after coronary angioplasty, and vascular sclerosis during transplantation, suggesting that latent virus is reactivated during immunosuppression and contributes to adverse effects $[9,15]$. animals CMV in the presence of platelets increased the influx of T-lymphocytes to atherosclerotic plaques and neutrophil extravasation [9].

Infection with the human influenza virus can lead to acute coronary syndrome and myocardial infarction [15]. Animal experiments have shown that influenza causes inflammatory and thrombotic reactions in atherosclerotic plaques and reduces the protective role of high-density lipoproteins [15, 16].

Platelets can bind CMV via TLR2, which triggers platelet activation and degranulation and enhances platelet-toneutrophil interaction. It has recently been shown that encephalomyocarditis virus interacts with platelet TLR7, which also leads to platelet degranulation and direct interactions of platelets and neutrophils. Platelet fragments are subsequently phagocytosed by neutrophils, and this helps to reduce the number of platelets. Rotavirus uses the GPla/lla collagen receptor to bind to platelets, and hantavirus and adenoviruses interact with platelets through the GPIIb/
Illa fibrinogen receptor. However, GPIIb/IIla is not a unique receptor for platelet-to-adenovirus interaction, as inhibition of GPIIb/IIla does not alter the internalization of platelets and adenoviruses [8, 13].

Epshtein-Barr virus (EBV) interacts with platelets through the complement 2 receptor (CR2). HIV and Dengue virus activate platelets by binding to lectin receptors, such as the C-type lectin domain of family 2 (CLEC-2) and the cellspecific intercellular adhesion molecule-3-capturing nonintrigrin (DC-SIGN). Platelets and/or megakaryocytes can additionally interact with HIV envelope proteins via the $\mathrm{C}-\mathrm{X}$ - $C$ chemokine receptor type 4 (CXCR4) or via the chemokine (C - C) ligand (CCL) 3 (MIP-1 $1 \alpha$ ) and 5 (RANTES). However, HIV-1 changes the use of co-receptors from CCR5 to CXCR4 only after many years of infection, and this change in the receptor is a transition to non-CD4-dependent platelet activation in the later stages of the disease $[6,8]$.

These direct interactions often lead to platelet activation and adhesion of activated platelets to leukocytes. Binding of platelets to neutrophils triggers platelet phagocytosis, and platelet activation itself promotes platelet clearance in the spleen and liver.

However, platelets are activated not only by direct interaction with viruses. Host defense mechanisms in response to viral infections can also lead to platelet activation. For example, many viral infections lead to systemic inflammation, which in turn triggers platelet activation and reduces platelet life expectancy. In addition, influenza virus, rhinovirus, and CMV infection lead to increased regulation of cytokines such as interleukin 6 (IL-6) [9].

Platelets can be activated by cytokines, which leads to platelet-leukocyte interaction. This promotes the activation of leukocytes and endothelium by enhancing platelet activation and clearance by splenic macrophages or Kupffer cells in the liver. Monocytes that come in contact with the Dengue virus, for example, begin to generate platelet activating factor (PAF), which is a lipid mediator, which triggers platelet activation. This leads to increased platelet apoptosis and accelerates platelet clearance in secondary dengue infection [9, 12].

Some viral infections activate the coagulation cascade by inducing the expression of tissue factor in target cells. Generation of thrombin by the activated coagulation cascade causes platelet activation and subsequent clearance by protease-activating receptor signaling. Proteases on platelets, endothelial cells and leukocytes are important modulators in viral infections that modulate the innate immune response [7, 15].

Platelets also recognize immunoglobulin-coated viral particles through their FcyR II receptor, leading to Fc receptormediated activation, aggregation and clearance of platelets. Fcy RII-mediated platelet activation depends on the involvement of IgG and GP Ilb/llla and involves ADF and thromboxane $A 2$ feedback mechanisms to induce platelet aggregation [7, 12].

In addition, platelet destruction in response to viral 
infections may occur due to impaired portal vein pressure and increased platelet sequestration by an enlarged spleen, as is the case with HCV infection. [8, 15].

Immune thrombocytopenia has complex developmental mechanisms in chronic HCV infection. The development of $\mathrm{HCV}$-associated thrombocytopenia is autoimmune in nature and is accompanied by the production of antiplatelet autoantibodies. The primary immune defect is based on the production of autoantibodies tropical to platelet surface glycoproteins. B-lymphocytes are produced by surface glycoproteins due to the reduced level of autotolerance of Tlymphocytes. The inhibitory effect of HCV, which replicates in hematopoietic progenitor cells, on platelet production in the bone marrow and the positive effect of antiviral treatment of HCV-associated thrombocytopenia, in particular in cases of thrombocytopenia resistant to corticosteroids, have been demonstrated.

HCV- induced liver dysfunction leads to decreased TP production, which in turn leads to impaired platelet production in the bone marrow. Restoration of TP levels and an increase in platelet counts after successful liver transplantation in people infected with $\mathrm{HCV}$ underscores the importance of this mechanism in HCV-induced thrombocytopenia. Moreover, portal hypertension leads to platelet activation and reduces platelet survival due to increased platelet sequestration in the spleen $[4,8]$.

Thrombocytopenia, which is caused by the human immunodeficiency virus, has different mechanisms of occurrence. HIV has been shown to reduce the number and activity of megakaryocytes. Surface glycoprotein gp120 leads to increased apoptosis of megakaryocytes in vitro by increasing the TGF $\beta$ receptor and reducing the regulation of platelet proliferation. In addition, gp120 interacts with CD4 + , which is expressed by immature megakaryocytes, which also express CCR5, and leads to their infection. Megakaryocyte HIV infection can lead to decreased expression of TPO receptors (c-Mpl) [8].

Viruses also have enzymes that can modulate platelet function. For example, the influenza virus secretes neurominidase (sialidase), which hydrolyzes the terminal residues of sialic acid from the receptors of host cells and thereby shortens the lifespan of platelets. In addition to affecting platelet life expectancy, neurominidase further alters megakaryocyte ploidy, as well as platelet morphology and size $[10,14]$.

The interaction of platelets and leukocytes and the modulation of leukocyte functions can be further accelerated by the binding of CD40 ligand (CD40L/CD154) to CD40. Platelets express and secrete (soluble) CD154, thereby causing a host reaction and exacerbating inflammation.

Platelets interact directly with T-lymphocytes and Blymphocytes and modulate their function through direct cell-

\section{References}

1. Vydyborets, S. V. (2017). Trombotsytopeniia yak dyferentsiinodiahnostychna problema u klinichniy praktytsy [Thrombocytopenia as a differential diagnostic problem in cell interactions as well as soluble mediators. Plateletreleased CXCL4 and CCL5 enhance the production of proand anti-inflammatory cytokines by $\mathrm{T}$ lymphocytes. CXCL4 is an important mediator in $\mathrm{T}$ cell differentiation, leading to an increase in regulatory $\mathrm{T}$ lymphocytes and limiting Th17 differentiation $[8,14]$.

Binding of IgG-coated viruses causes the expression of platelets CD154 and CCL5, which, in turn, primers the protective T-cell mediated immunity [4, 14].

It remains unclear to what extent platelet interactions with the virus are beneficial to the host. Potentially adverse effects of platelet interaction with the virus can be observed in HIV infection. In response to the interaction with HIV, platelets become active and release CCL5, leading to the accumulation of highly sensitive target cells such as $T$ lymphocytes and monocytes. HCV has also been shown to take advantage of platelets as a safe transport system to reach the liver, where platelet activation further enhances the interaction of platelets and liver cells. This interaction prolongs the time of possible infection of the liver tissue with the virus $[4,8,10]$.

Taken together, viruses can either increase platelet activation, leading to prothrombotic events, or reduce platelet response, thereby leading to bleeding. Platelet counts are insufficient to predict adverse platelet effects, and parameters such as platelet activation and reactivity may be more accurate in predicting the risk of bleeding in patients.

\section{Conclusions and prospects for further development}

1. Thrombocytopenia is a common complication of viral infections and viruses use different strategies to trigger the mechanism of platelet breakdown, and also play a key role in maintaining adequate host responses.

2. Viruses can cause induction of autoimmune response due to: molecular mimicry between viruses and platelets, production of anti-idiotypic antibodies to antiviral antibodies, increased expression of MCN-HLA class I and II molecules, which are very similar to certain regions of viral genomes, host immune changes in endogenous antigens.

3. The immune response underlying the development of thrombocytopenia is a cyclic multistage process involving T-lymphocytes, B-lymphocytes, macrophages, cytokines, $\mathrm{Nk}$ - cells. Antiplatelet antibodies accelerate the clearance of platelets from the circulation. Binding of antibodies to platelets results in Fcy receptor-mediated disintegration of platelets by phagocytes.

Prospects for further research is to study the interaction of platelets with different types of viruses, the viral effect on platelet activation. Research aimed at further study of platelet-mediated modulation of adaptive immune responses is promising.

clinical practice]. Simeina medycina - Family medicine, 2 (70), 129-131. Взято 3 http://nbuv.gov.ua/UJRN/ simmed_2017_2_28 
2. Melykian, A. L., Pustova, O. I., Yehorova, O. K., Kalynyna, M. V. Kolosheinova, T. Y., Subortseva, Y. N., ... \& Dvyrnyk, V. N. (2017). Dyferentsiina diahnostyka trombotsytopenii [Differential diagnosis of thrombocytopenia]. Onkohematolohiia Oncohematology, 12 (1), 79. https://doi.org/10.17650/18188346-2017-12-1-78-87

3. Piasetska, N. M. (2014). Trombotsytopeniia novonarodzhenykh - klinichna kharakterystyka, laboratorna diahnostyka ta likuvannia (klinichna lektsiia) [Neonatal thrombocytopenia clinical characteristics, laboratory diagnosis and treatment (clinical lecture)]. Neonatolohiia, khirurhiia ta perynatalna medytsyna - Neonatology, Surgery and Perinatal Medicine, 4 (1), 83-93. Vziato $z$ http://nbuv.gov.ua/UJRN/ Nkhpm 2014_4_1_17

4. Riabokon, Yu. Yu. (2012). Vypadok HCV-asotsiiovanoi imunnoi trombotsytopenii u khvoroho na khronichnyi hepatyt C [A case of $\mathrm{HCV}$-associated immune thrombocytopenia in a patient with chronic hepatitis C]. Patolohiia - Pathology, 1 (24), 101-102. Vziato z http://nbuv.gov.ua/UJRN/pathology_2012_1_26

5. Tkachenko, V. I., Alekseichenko, O. I., \& Horishnii, I. I. (2017). Syndrom trombotsytopenii u praktytsi simeinoho likaria [Thrombocytopenia syndrome in the practice of a family doctor]. Simeina medytsyna - Family Medicine, 5 (73), 7882. Vziato z http://nbuv.gov.ua/UJRN/simmed_2017_5_20

6. Shejbak, L. N. (2015). Tromboczitopenii u novorozhdenny'kh detej [Thrombocytopenia in newborns]. Problemy zdorov'ya $i$ e'kologii - Problems of health and ecology, 20-25. Vzyato s https://cyberleninka.ru/article/n/trombotsitopenii-unovorozhdennyh-detey/viewer

7. Antoniak, S., \& Mackman, N. (2014). Multiple roles of the coagulation protease cascade during virus infection. Blood, 123 (17), 2605-2613. doi: 10.1182/blood-2013-09-526277

8. Assinger, A. (2014). Platelets and infection - an emerging role of platelets in viral infection. Frontiers in Immunology, 5 (649), 1-12. doi: 10.3389/fimmu.2014.00649

9. Assinger, A., Kral, J. B., Yaiw, K. C., Schrottmaier, W. C., Kurzejamska, E., Wang, Y., ... \& Söderberg-Naucler, C. (2014). Human cytomegalovirus-platelet interaction triggers toll-like receptor 2-dependent proinflammatory and proangiogenic responses. Arterioscler Thromb. Vasc. Biol., 34 (4), $801-$ 809. doi: 10.1161/ATVBAHA. 114.303287

10. Bunce, P. E., High, S. M., Nadjafi, M., Stanley, K., Liles, W. C., \& Christian, M. D. (2011). Pandemic H1N1 influenza infection and vascular thrombosis. Clin. Infect. Dis., 52 (2), 14-17. doi: $10.1093 / \mathrm{cid} / \mathrm{ciq} 125$

11. Michels, M., Alisjahbana, B., De Groot, P. G., Indrati, A. R., Fijnheer, R., Puspita, M., ... \& de Mast, Q. (2014). Platelet function alterations in dengue are associated with plasma leakage. Thromb. Haemost., 112 (2), 352-362. doi:10.1160/ TH14-01-0056

12. Nascimento, E. J., Hottz, E. D., Garcia-Bates, T. M., Bozza, F., Marques, E. T., \& Barratt-Boyes, S. M. (2014). Emerging concepts in dengue pathogenesis: interplay between plasmablasts, platelets, and complement in triggering vasculopathy. Crit. Rev. Immunol., 34 (3), 227-240, doi: 10.1615/CritRevImmunol.2014010212

13. Neunert, C., Lim, W., Crowther, M., Cohen, A., \& Solberg, L. Jr. (2011). The American Society of Hematology 2011 evidencebased practice guideline for immune throm bocytopenia. Blood, 117 (16), 4190-4207. doi:10.1182/blood2010-08-302984

14. Rondina, M. T., Brewster, B., Grissom, C. K., Zimmerman, G. A., Kastendieck, D. H., Harris, E. S., \& Weyrich, A. S. (2012). In vivo platelet activation in critically ill patients with primary 2009 influenza $A(\mathrm{H} 1 \mathrm{N1} 1)$. Chest, 141 (6), 1490-1495. doi: 10.1378/ chest.11-2860

15. Rosenfeld, M. E., \& Campbell, L. A. (2011). Pathogens and atherosclerosis: update on the potential contribution of multiple infectious organisms to the pathogenesis of atherosclerosis. Thromb. Haemost., 106 (5), 858-867. doi:10.1160/ TH11-060392/

16. Tufano, A., Di Capua, M., Coppola, A., Conca, P., Cimino, E., Cerbone, A. M., Di Minno, G. (2012). The infectious burden in atherothrombosis. Semin. Thromb. Hemost., 38 (5), 515-523. doi: 10.1055/s-0032-1315759

17. Provan, D., Stasi, R., Newlnd, A. C., Blanchette, V. S., BoltonMaggs, P., Bussel, J. B., ... \& Kuter, D. J. (2010). International consensus report on the investigation and management of primary immune thrombocytopenia. Blood, 115, 168-86. DOI: 10.1182/blood-2009-06-225565

18. Fogarty, P., \& Segal, J. (2007). The epidemiology of immune thrombocytopenic purpura. Curr. Opin. Hematol., 14 (5), 515519. doi: 10.1097/MOH.0b013e3282ab98c7

19. Gauer, R. L., \& Braun, M. M. (2012). Thrombocytopenia. Am. Fam. Physician., 85 (6), 612-622. Retrieved from https:// pubmed.ncbi.nlm.nih.gov/22534274/

20. Beck, O. N. (2009). Thrombocytopenia. (Ch. 11). (p. 273-288). In Diagnostic hematology. London. ISBN 978-1-84800-295-1. https://doi.org/10.1007/978-1-84800-295-1

21. Jain, S., Kamimoto, L., Bramley, A. M., Schmitz, A. M., Benoit, S. R., Louie, J., ... \& Deutscher, M. (2009). Hospitalized Patients with 2009 H1N1 Influenza in the United States, April-June 2009. N. Engl. J. Med., 361, 1935-1944. DOI: 10.1056/ NEJMoa0906695

\section{Список посилань}

1. Видиборець, С. В. (2017). Тромбоцитопенія, як диференційно-діагностична проблема у клінічній практиці. Сімейна медицина, 2 (70), 129-131. Взято з http://nbuv.gov.ua/UJRN/ simmed 2017228

2. Меликян, А. Л., Пустова, О. І., Єгорова, О. К., Калинина, М. В., Колошейнова, Т. И., Суборцева, И. Н., ... \& Двирник, В. Н. (2017). Дифреренційна діагностика тромбоцитопеній. Онкогематологія, 12 (1), 79. https://doi.org/10.17650/18188346-2017-12-1-78-87

3. Пясецька, Н. М. (2014). Тромбоцитопенія новонароджених клінічна характеристика, лабораторна діагностика та лікування (клінічна лекція). Неонатологія, хірургія та перинатальна медицина, 4 (1), 83-93. Взято з http://nbuv.gov.ua/ UJRN/Nkhpm_2014_4_1_17

4. Рябоконь, Ю. Ю. (2012). Випадок HCV-асоційованої імунної тромбоцитопенії у хворого на хронічний гепатит С. Патологія, 1 (24), 101-102. Взято з http://nbuv.gov.ua/UJRN/ pathology_2012_1_26

5. Ткаченко, В. І., Алексейченко, О. І., \& Горішній, І. І. (2017). Синдром тромбоцитопенії у практиці сімейного лікаря. Сімейна медицина, 5 (73), 78-82. Взято з http://nbuv.gov.ua/ UJRN/simmed 2017520

6. Шейбак, Л. Н. (2015). Тромбоцитопении у новорожденных детей. Проблемы здоровья и экологии, 20-25. Взято с https://cyberleninka.ru/article/n/trombotsitopenii-unovorozhdennyh-detey/viewer

7. Antoniak, S., \& Mackman, N. (2014). Multiple roles of the coagulation protease cascade during virus infection. Blood, 123 (17), 2605-2613. doi: 10.1182/blood-2013-09-526277

8. Assinger, A. (2014). Platelets and infection - an emerging role of platelets in viral infection. Frontiers in Immunology, 5 (649), 1-12. doi: 10.3389/fimmu.2014.00649

9. Assinger, A., Kral, J. B., Yaiw, K. C., Schrottmaier, W. C., Kurzejamska, E., Wang, Y., ... \& S?derberg-Naucler, C. (2014). Human cytomegalovirus-platelet interaction triggers toll-like receptor 2-dependent proinflammatory and proangiogenic responses. Arterioscler Thromb. Vasc. Biol., 34 (4), 801809. doi: 10.1161/ATVBAHA.114.303287 
10. Bunce, P. E., High, S. M., Nadjafi, M., Stanley, K., Liles, W. C., \& Christian, M. D. (2011). Pandemic H1N1 influenza infection and vascular thrombosis. Clin. Infect. Dis., 52 (2), 14-17. doi: 10.1093/cid/ciq125

11. Michels, M., Alisjahbana, B., De Groot, P. G., Indrati, A. R., Fijnheer, R., Puspita, M., ... \& de Mast, Q. (2014). Platelet function alterations in dengue are associated with plasma leakage. Thromb. Haemost., 112 (2), 352-362. doi:10.1160/ TH14-01-0056

12. Nascimento, E. J., Hottz, E. D., Garcia-Bates, T. M., Bozza, F., Marques, E. T., \& Barratt-Boyes, S. M. (2014). Emerging concepts in dengue pathogenesis: interplay between plasmablasts, platelets, and complement in triggering vasculopathy. Crit. Rev. Immunol., 34 (3), 227-240, doi: 10.1615/CritRevlmmunol.2014010212

13. Neunert, C., Lim, W., Crowther, M., Cohen, A., \& Solberg, L. Jr. (2011). The American Society of Hematology 2011 evidencebased practice guideline for immune throm bocytopenia. Blood, 117 (16), 4190-4207. doi:10.1182/blood2010-08-302984

14. Rondina, M. T., Brewster, B., Grissom, C. K., Zimmerman, G. A., Kastendieck, D. H., Harris, E. S., \& Weyrich, A. S. (2012). In vivo platelet activation in critically ill patients with primary 2009 influenza $A(H 1 N 1)$. Chest, 141 (6), 1490-1495. doi: 10.1378/ chest.11-2860

15. Rosenfeld, M. E., \& Campbell, L. A. (2011). Pathogens and atherosclerosis: update on the potential contribution of multiple infectious organisms to the pathogenesis of atherosclerosis Thromb. Haemost., 106 (5), 858-867. doi:10.1160/ TH11-060392/

16. Tufano, A., Di Capua, M., Coppola, A., Conca, P., Cimino, E., Cerbone, A. M., Di Minno, G. (2012). The infectious burden in atherothrombosis. Semin. Thromb. Hemost., 38 (5), 515-523. doi: $10.1055 / \mathrm{s}-0032-1315759$

17. Provan, D., Stasi, R., Newind, A. C., Blanchette, V. S., BoltonMaggs, P., Bussel, J. B., ... \& Kuter, D. J. (2010). International consensus report on the investigation and management of primary immune thrombocytopenia. Blood, 115, 168-86. DOI: 10.1182/blood-2009-06-225565

18. Fogarty, P., \& Segal, J. (2007). The epidemiology of immune thrombocytopenic purpura. Curr. Opin. Hematol., 14 (5), 515519. doi: 10.1097/MOH.0b013e3282ab98c7

19. Gauer, R. L., \& Braun, M. M. (2012). Thrombocytopenia. Am. Fam. Physician., 85 (6), 612-622. Retrieved from https:// pubmed.ncbi.nlm.nih.gov/22534274/

20. Beck, O. N. (2009). Thrombocytopenia. (Ch. 11). (p. 273-288). In Diagnostic hematology. London. ISBN 978-1-84800-295-1. https://doi.org/10.1007/978-1-84800-295-1

21. Jain, S., Kamimoto, L., Bramley, A. M., Schmitz, A. M., Benoit, S. R., Louie, J., ... \& Deutscher, M. (2009). Hospitalized Patients with 2009 H1N1 Influenza in the United States, April-June 2009. N. Engl. J. Med., 361, 1935-1944. DOI: 10.1056/ NEJMoa0906695

\section{ОСОБЛИВОСТІ ПАТОГЕНЕТИЧНИХ МЕХАНІЗМІВ ВЗАЄМОДІЇ ВІРУСІВ ТА ТРОМБОЦИТІВ У ХВОРИХ 3 ІМУННОЮ ТРОМБОЦИТОПЕНІЄЮ (ОГЛЯД ЛІТЕРАТУРИ)}

\section{Дудник В. М., Фурман В. Г., Ізюмець О. І., Федчишен А. П., Сінчук Н. І., Куцак О. В.}

Анотація. Однією з актуальних міждисциплінарних проблем сучасної медицини є вивчення механізмів розвитку вірус-індукованої імунної тромбоцитопенії у хворих. Мета роботи - узагальнити сучасні знання щодо особливостей взаємодії тромбоцитів із різними типами вірусів, їх впливу на активацію тромбоцитів та опосередковану тромбоцитами модуляцію адаптивних імунних реакцій у хворих з імунною тромбоцитопенією. Було проведено систематичний огляд статей бази даних Pub Med між 2007 та 2020 рокам, використовуючи пошукові терміни: тромбоцити, тромбоцитопенія, вірусна інфрекція. Проаналізували сучасні дані щодо вивчення механізмів взаємодії тромбоцитів з різними типами вірусів при імунних тромбоцитопеніях у дітей. Розглянули аспекти активації тромбоцитів вірусною інфрекцією та імунної реакції, що лежить в основі розвитку тромбоцитопенії. Відомо, що імунна реакція $є$ циклічним багатоступеневим процесом, в якому приймають участь Т-лімфоцити, В-лімфоцити, макрофраги, цитокіни, NК-клітини. Антитромбоцитарні антитіла прискорюють кліренс тромбоцитів із циркуляції. Зв'язування антитіл з тромбоцитами призводить до опосередкованого рецептором Fсу розпаду тромбоцитів фагоцитами. У пацієнтів з імунною тромбоцитопенічною пурпурою виробляються головним чином IgGаутоантитіла проти глікопротеїнів GP/II в/III а або GP/I в/IX поверхні тромбоцитів. У даній ситуації можлива виробка антитіл інших підкласів IgG, комплемент фріксуючих IgM, і рідше, IgA до інших глікопротеїнів, або до їх комплексів, таких як lв IX, Іа/Ila. Оскільки мегакаріоцити експресують глікопротеїн Ilв/IIIa, Ів та інші антигени тромбоцитів, вони також стають мішенню для аутоантитіл. Віруси можуть безпосередньо взаємодіяти з тромбоцитами і мегакаріоцитами. Крім того, тромбоцити можуть активуватися вірусними комплексами антиген-антитіло, і у відповідь на деякі віруси В-лімфоцити можуть генерувати антитромбоцитарні антитіла. Усі ці процеси, що сприяють активації тромбоцитів, призводять до збільшеного споживання та видалення тромбоцитів, що стає причиною геморагічних проявів у хворих.

Ключові слова: тромбоцити, тромбоцитопенія, вірусна інфекція, хворі.

\section{ОСОБЕННОСТИ ПАТОГЕНЕТИЧЕСКИХ МЕХАНИЗМОВ ВЗАИМОДЕЙСТВИЯ ВИРУСОВ И ТРОМБОЦИТОВ У БОЛЬНЫХ С ИММУННОЙ ТРОМБОЦИТОПЕНИЕЙ (ОБЗОР ЛИТЕРАТУРЫ) \\ Дудник В. М., Фурман В. Г., Изюмец О. И., Федчишен А. П., Синчук Н. И., Куцак О. В.}

Аннотация. Одной из актуальных междисциплинарных проблем современной медицины является изучение механизмов развития вирус-индуцированной иммунной тромбоцитопении у больных. Цель работы - обобщить современные знания, касающиеся особенностей взаимодействия тромбоцитов с различными типами вирусов, их влияния на активацию тромбоцитов и опосредованную тромбоцитами модуляцию адаптивных иммунных реакций у больных с иммунной тромбоцитопенией. Был проведен систематический обзор статей базы данных Pub Med между 2007 и 2020 годами, используя поисковые термины: тромбоциты, тромбоцитопения, вирусная инфекция. Проанализировали современные данные, касающихся изучения механизмов взаимодействия тромбоцитов с различными типами вирусов при иммунных тромбоцитопениях у детей. Рассмотрены аспекты активации тромбоцитов вирусной инфекцией и также иммунной реакции, которая лежит в основе развития тромбоцитопении. Известно, что иммунная реакция - это циклический многоступенчатый процесс, в котором принимают участия T-лимфоциты, В-лимфоциты, макрофраги, цитокины, NK-клетки. Антитромбоцитарные антитела ускоряют клиренс тромбоцитов из циркуляции. Связывание антител с тромбоцитами приводит к опосредован- 
ному рецептором Fсу распаду тромбоцитов фагоцитами. У пациентов с иммунной тромбоцитопенией вырабатываются главным образом IgG-аутоантитела на гликопротеины GP/II в/III, или GP/I в IX поверхности тромбоцитов. Так как мегакариоциты экспрессируют гликопротеин ІІв/IIla, Ів и другие антигены тромбоцитов, они также стают мишенью для аутоантител. Вирусы могут непосредственно взаимодействовать с тромбоцитами и мегакариоцитами. Тромбоциты могут активироваться вирусными комплексами антиген-антитело, и в ответ на некоторые вирусы В-лимсоциты могут вырабатывать антитромбоцитарные антитела. Все эти процессы, которые способствуют активации тромбоцитов, приводят к увеличению потребления и удаления тромбоцитов, что служит причиной геморрагических проявлений у больных. Ключевые слова: тромбоциты, тромбоцитопения, вирусная инфрекция, больные. 